ranted in concluding that upwards of 500 animals were deposited in that limited space.

The coloured map of the German Ocean exhibited at the meeting, showed the localities whence the organic remains are chiefly taken; certain spots marked thereon are the fishing-grounds, and, therefore, the depositories of the fossils with which we are made familiar; but we cannot doubt that these exuviæ are more generally distributed orer the sea-bottom. The following specimens were exhibited:-Teeth of three species of elephant, Elephas primigenius, $\boldsymbol{E}$. antiquus, and $E$. meridionalis ; cervical and dorsal vertebræ of the same genus; two teeth of a hippopotamus (a dorsal vertebra has since been brought up) ; a dorsal vertebra of a whale ; a unique specimen of a lower jaw of the Trichechus rosmarus; heads of the Megaceros Hibernicus, male and female; an anterior dorsal vertebra of ditto (an antler, 4 feet 6 inches long, has since been brought me) ; atlas of ditto; a fragment of an antler of Cervus tarandus; the humerus of a gigantic ox; a portion of the head of the Equus fossilis; and a fine specimen of Castor Europaus, the head. The colour of these specimens might lead us to believe that they belonged to the Mammaliferous Crag period; but colour is not a decisive criterion. It is probable that they may have lain in close proximity to a bed of crag ; they are unquestionably from a Pleistocene deposit.

And, now, as to how these organic remains came to be at the bottom of the ocean. At a not very remote geological period our island was united with the continent; a catastrophe took place which separated them and led to the formation of the German Ocean. This gap has been continually enlarging, from the crumbling down of the cliffs on either side; the fossils have thus been exhumed, carried out to sea during storms by retiring waves, and there deposited. No doubt, also, that many remains which lie buried in the land that originally united us to the continent sank bodily with it, and consequently they are met with when the sea-bottom is raked over by the trawling-nets of the fishermen.

P.S.-I give the measurement of three tusks. One, belonging to $\mathrm{Mr}$. Owles, measures-length of external curve, 7 feet 5 inches; girth at proximal end, 18 inches; radius of inner curve, 3 feet.

$I$ possess two perfect tusks-one, length, 6 feet 3 inches ; girth, 17 inches; radius of curve, 3 feet 3 inches: the other, length, 6 feet ; girth, $12 \frac{1}{2}$ inches; radius of curve, 4 feet 2 inches. These proportions indicate that my specimens are from two distinct species of the elephant.

A femur of the mammoth in my possession measures 3 feet 5 inches, minus the head of the bone, which is gone.

The late Rev. Mr. Layton possessed the finest collection of mammalian remains from the Norfolk coast. At his death it was purchased for the British Museum.

\title{
NOTES ON DEEP OR ARTESIAN WELLS AT NORWICH.
}

BY the Rev. J. Crompton.

The object of this paper is to put on record the facts connected with the attempt now being made by Messrs. J. and J. Colman, of London and Norwich, to bore a deep well through the chalk to the Lower Greensand. Mr. Rose, of Yarmouth, in the 'Proceedings of the Geologists' Associa-

* The atles of the Megaceros has a Turritella incrassata (Crag fossil) sticking in the canal for the vertebral artery. 
tion,' No. 8, 1862, has mentioned some of these facts, but it seemed worth while to throw them together in a distinct memorial, if only to draw attention to an enterprising and patiently-conducted operation of great extent, by a single commercial firm, in obedience to geological principles.

The wells (for there have been two attempts) are situated at the foot of Carrow and Bracondale Hill, Norwich, within a few yards of the river Wensum, the object of the deep sinking being to obtain a water, for use in the manufacture of starch, perfectly free from the impurities of that found within the range of the chalk of the neighbourhood.

The operation chosen is that of boring by Messrs. Mather and Platt's machine. This machine consists of an iron boring-head, 8 or 10 feet in length, armed with strong chisels, suspended by a flat rope wound round a drum ; the hammering or "jumping" motion being given by a special steam piston. The neck of the borer is formed with a screw, on which a collar connected with the flat rope works, the effect being that the borer is gradually twisted when at work, so that the chisels constantly strike on fresh points, and more thoroughly break up the materials met with. When a sufficient quantity has been thus broken up, the boring-head is removed and a "shell-pump" is let down having a valve at the base. On the pump being set in action, the loose material is forced into the shell and brought to the surface. In the hard chalk the rate of penetration accomplished was 20 to 25 feet a day for 500 feet.

The first well failed in consequence of the iron tubing employed to case the bore slipping across and completely obstructing the action of the machine, at a depth of 775 feet.

The second is being sunk a few yards off, on the same level as the first.

After a few feet of alluvium the borer passed through hard chalk, with flints at distances of about 6 or 7 feet apart, for 700 feet, with the exception of 10 feet at the depth of 500 feet, where the rock was soft, "like white lead," and of a rusty colour. Thence the hard chalk continued, with flints thicker together, viz. about 4 feet apart, to the depth of 1050 feet. Then 102 feet were pierced, of chalk free from fints, to the Upper Greensand, a stratum of about 6 feet, and next the gault for 36 feet: the whole boring being full of water to within 16 feet of the surface.

In this gault, however, the greatest obstacle has been met, and the completion of the work arrested for a considerable time past. This stratum is soft, so that the chisels, effective in the harder upper strata, are of little use. The material caves in from all sides as the instrument proceeds, and, unfortunately, the rope has broken more than once, leaving the boringhead below, and one now lying across the bore baffles the engineer's efforts to remove it.

The strata passed through are-

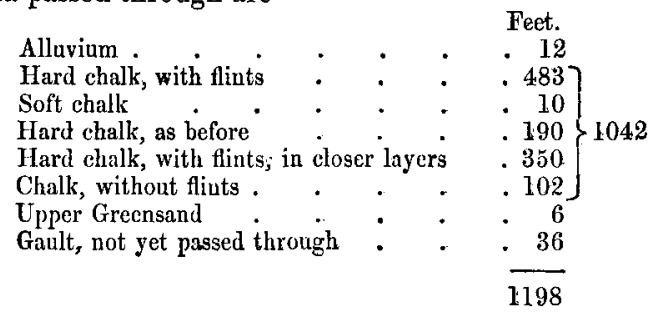

The fossils brought up have not been very mumerous, as might be expected from the smallness of the bore, viz. twenty-one inches in diameter. 
The larger proportion have been from the lower strata, especially the ganlt.

From the chalk the ordinary fossils, as the Spatangus cordiformis, have been taken; three sharks' teeth, one that of Lamna Mantellii. From the gault, as noticed by Mr. Rose, characteristic small Belemnites, with Ammonites lautus, Ammonites symmetricus, and fragments of Inoceramus.

The Foraminifera as yet detected by my friend Mr. Kitton, of Norwich, whose accuracy of observation as well as kindness I have to thank, arein the gault, Orbulina (common); Lagena (rare); Nodosaria (not uncommon); Frondicularia (rare); Dentalina (not uncommon); Entosolenia (rare); Rotalina (not uncommon); Polymorphina (ditto); Textularia (common); Globigerina (ditto). Fragments of Bryozoa occasionally occur.

In the chalk at 500 feet depth the Foraminifera are more sparsely distributed, and much more injured than in the gault. They consist principally of two genera, Globigerina and Textularia. Rotalina are somewhat more rare. The same is the case with the samples examined from 110,400 , and 1000 feet in depth.

The work, from the unfortunate cause mentioned, is arrested apparently on the point of success, to the great annoyance of the enterprising proprietors ; and, although our business here is with the scientific facts presented, the geological section will not hesitate to recognize one more instance in which the science of geology has received practical homage from a private commercial firm in a work of considerable boldness, carried on for three years in the face of temporary defeats, with admirable courage and faith in the dictates of geology.

The other papers read in the Geological Section were:-Opening Address by Mr. J. B. Jukes; "On a Whittled Bone from the Barnwell Grarel," by Mr. Harry Seeley ; “ On Tertiary Coal," by Prof. Ansted; "Alluvial Deposits on the Rhine," by R. H. C. Godwin-Austen, F.R.S.; "On an Ancient Sea-beach at Fort William," by Mr. J. Gwyn Jeffreys; "Glacial Deposits of Highlands of Scotland," by Rev. S. W. King ; "On Wookey Hole Hyæna Den," by Mr. W. Boyd Dawkins; "Last Eruption of Vesuvius," by Dr. Daubeny ; "Extinct Volcano in Upper Burmah," by Mr. W. T. Blandford ; " Comparative Structure of Artificial and Natural Igneous Rocks," by H. C. Sorby, F.R.S.; "General Review of Cambrian Rocks," and "Older Metamorphic Rocks and their Fossil Contents," by Dr. Bigsby ; "Contributions to Australian Mesozoic Geology," by Mr. C. Moore ; "Correlation of Iron-slates and Limestones of Devon and Corn." wall with Old Red Sandstone of Scotland," by Mr. W. Pengelly ; "Sixinch Maps of Bronan district, Co. Clare," by Mr. F. J. Foot; "Goldfields of Auckland" and "Gold-fields of Otago," by Dr. L. W. Lindsay; "Tooth of Mastodon from Tertiary Marls, Shanghai," by Prof. Owen; "New Recent Echinoderm and its probable Palæontological Affinities," by Dr. Allman ; "Identity of Upper Old Red Sandstone with the Uppermost Devonian, and of the Middle and Lower Old Red with the Middle and Lower Devonian," by Mr.J. W. Salter ; "Skull of Rhinoceros tichorhinus," by S. P. Saville; "Supplementary Report on Slaty Cleavage," by Prof. Phillips ; "Composition of Granite of Donegal," by Dr. T. Sterry Hunt; "Ossiferous Caves in Malta," by Dr. Falconer ; "Glacial Phenomena of Upper Indus," by Captain Godwin-Austen ; "Fossils of Boulder Clay in Caithness," by Mr. C. W. Peach; "Mammalian Remains from Bed of Grerman Ocean," by Mr. C. B. Rose; " Flint Implements 
The larger proportion have been from the lower strata, especially the ganlt.

From the chalk the ordinary fossils, as the Spatangus cordiformis, have been taken; three sharks' teeth, one that of Lamna Mantellii. From the gault, as noticed by Mr. Rose, characteristic small Belemnites, with Ammonites lautus, Ammonites symmetricus, and fragments of Inoceramus.

The Foraminifera as yet detected by my friend Mr. Kitton, of Norwich, whose accuracy of observation as well as kindness I have to thank, arein the gault, Orbulina (common); Lagena (rare); Nodosaria (not uncommon); Frondicularia (rare); Dentalina (not uncommon); Entosolenia (rare); Rotalina (not uncommon); Polymorphina (ditto); Textularia (common); Globigerina (ditto). Fragments of Bryozoa occasionally occur.

In the chalk at 500 feet depth the Foraminifera are more sparsely distributed, and much more injured than in the gault. They consist principally of two genera, Globigerina and Textularia. Rotalina are somewhat more rare. The same is the case with the samples examined from 110,400 , and 1000 feet in depth.

The work, from the unfortunate cause mentioned, is arrested apparently on the point of success, to the great annoyance of the enterprising proprietors ; and, although our business here is with the scientific facts presented, the geological section will not hesitate to recognize one more instance in which the science of geology has received practical homage from a private commercial firm in a work of considerable boldness, carried on for three years in the face of temporary defeats, with admirable courage and faith in the dictates of geology.

The other papers read in the Geological Section were:-Opening Address by Mr. J. B. Jukes; "On a Whittled Bone from the Barnwell Grarel," by Mr. Harry Seeley ; “ On Tertiary Coal," by Prof. Ansted; "Alluvial Deposits on the Rhine," by R. H. C. Godwin-Austen, F.R.S.; "On an Ancient Sea-beach at Fort William," by Mr. J. Gwyn Jeffreys; "Glacial Deposits of Highlands of Scotland," by Rev. S. W. King ; "On Wookey Hole Hyæna Den," by Mr. W. Boyd Dawkins; "Last Eruption of Vesuvius," by Dr. Daubeny ; "Extinct Volcano in Upper Burmah," by Mr. W. T. Blandford ; " Comparative Structure of Artificial and Natural Igneous Rocks," by H. C. Sorby, F.R.S.; "General Review of Cambrian Rocks," and "Older Metamorphic Rocks and their Fossil Contents," by Dr. Bigsby ; "Contributions to Australian Mesozoic Geology," by Mr. C. Moore ; "Correlation of Iron-slates and Limestones of Devon and Corn." wall with Old Red Sandstone of Scotland," by Mr. W. Pengelly ; "Sixinch Maps of Bronan district, Co. Clare," by Mr. F. J. Foot; "Goldfields of Auckland" and "Gold-fields of Otago," by Dr. L. W. Lindsay; "Tooth of Mastodon from Tertiary Marls, Shanghai," by Prof. Owen; "New Recent Echinoderm and its probable Palæontological Affinities," by Dr. Allman ; "Identity of Upper Old Red Sandstone with the Uppermost Devonian, and of the Middle and Lower Old Red with the Middle and Lower Devonian," by Mr.J. W. Salter ; "Skull of Rhinoceros tichorhinus," by S. P. Saville; "Supplementary Report on Slaty Cleavage," by Prof. Phillips ; "Composition of Granite of Donegal," by Dr. T. Sterry Hunt; "Ossiferous Caves in Malta," by Dr. Falconer ; "Glacial Phenomena of Upper Indus," by Captain Godwin-Austen ; "Fossils of Boulder Clay in Caithness," by Mr. C. W. Peach; "Mammalian Remains from Bed of Grerman Ocean," by Mr. C. B. Rose; " Flint Implements 
from North Devon," by Rev. J. Dingle; "Veins in the Models of Foraminifera," by Dr. Pritsch; "Diluvial and Alluvial Deposits of Central Germany, and on the Climate of the Period," by Dr. von Seebach ; "On Petroleum of North America," and "Structure and Origin of Certain Limestones and Dolomites," by Dr. 'T. Sterry Hunt; "Plesiosaurus from Lias of Whitby," by Mr. F. J.Foot; " Flint Implements from the 'Oyle" Care, Tenby," by Mr. G. N. Smith; "Scutes of Labyrinthodon from Keuper Bone-Breccia of Pendock," by Rov. W. S. Symonds; "New Fossil Fishes from Old Red Sandstone, Caithness," by Mr. C. W. Peach.

\section{PROCEEDINGS OF GEOLOGICAL SOCIETIES.}

Geological Societr.-November 5, 1862.-Professor A. C. Ramsay, President, in the chair.-1. "Descriptions of some Fossils from India, discovered by Dr. Fleming of Edinburgh." By Dr. L. de Koninck.

The author gave a detailed description of 44 species of fossils from the western end of the salt-range of the Punjaub, on the right bank of the Indus, discovered by Dr. J. Fleming and Mr. W. Purdon. The same mixture of Mesozoic with Palæozoic types observed by Mr. Davidson, who described the Brachiopoda (Quart. Journ. Geol. Soc. vol. xviii. p. 25), was also noticed by the author in these fossils. He therefore suggests the possibility of a further examination of the strata showing the existence of two intimately associated formations, belonging respectively to the Carboniferous and Lower Mesozoic periods.

2. "On a Deposit containing Diatomacex, Leaves, etc., in the Iron-ore Mines near Ulverston." By Miss E. Hodgson.

The object of this paper was to show that this deposit, which was first described by Mr. Bolton in the Society's Journal, vol. xviii. p. 274, and considered by him to be of lacustrine origin, was deposited in a large cavern or chain of caverns by a subterranean stream originating probably in a brook ealled the " Poaka Beck."

3. "On the Geology of a Part of the Masulipatam District." By Capt. F. Applegarth, Madras Army.

4. "On the Association of Granite with the Tertiary Strata near King. ston." By J. G. Sawkins, Esq., F.G.S.

A granitic formation traverses Jamaica in a direction from S.E. to N.W., being the same as that of the earthquake-shocks. It pierces the Carbonaceous series, and also the Tertiary strata, whence the author concludes that it is of Tertiary age.

Manchester Geological Society.-June 24th.-Mr. Hull, of the Geological Survey, drew attention to the presence of Goniatites, Aviculopecten papyraceus, and other marine shells in the upper coal-measures at Dukinfield. It has always been considered that these marine fossils were confined to the lower coal-measures, and to the series of strata below the Arley mine.

Mr. Binney delivered an address "On the Geology of Manchester." The surface around Manchester was covered by drift, except in the valleys, where the rivers have cut through the drift. The drift of the district Mr. Binney divides into-

1. Valley gravel.-A bed of coarse gravel, composed of various-sized Azoic, Palæozoic, and a few Triassic rocks, well rounded, parted with layers of 